\title{
LANGUAGE, LITERATURE AND MUSIC IN SLOVENIAN CULTURAL AND POLITICAL ASPIRATIONS BEFORE 1914
}

\author{
NATAŠA CIGOJ KRSTULOVIĆ \\ Znanstvenoraziskovalni center SAZU, Ljubljana
}

Izvleček: Članek predstavlja prepletenost kulturnih in političnih prizadevanj Slovencev $v$ večnarodni habsburški monarhiji pred letom 1914. Študija primera (samo)reprezentativnih podob Slovencev v literaturi in glasbi izpostavlja odnos med popularnim repertoarjem v ljudskem duhu in izvirno ustvarjalnostjo ter njegov pomen pri oblikovanju narodne identitete in kulturnega spomina.

Ključne besede: 19. stoletje, kulturni nacionalizem, politični nacionalizem, kulturna identiteta, slovenska književnost, slovenska glasba.

\begin{abstract}
The article presents the interplay between cultural and political aspirations of Slovenians within the multinational Habsburg Empire before 1914. The case study of selfdefined images of Slovenians in literature and music outlines the relation between canonical and popular folk-like repertoires vs. original creativity and its meaning in formation of national identity and cultural memory.
\end{abstract}

Keywords: nineteenth century, cultural nationalism, political nationalism, cultural identity, Slovenian literature, Slovenian music.

Considering music in relation to society, culture and politics is currently an established way to understand nineteenth-century music. The perspective generally accepted in the humanities - that post-1848 demands for political independence of the nations of the Habsburg Empire were premised on a sense of cultural identity - has also been taken up by contemporary musicological thought. ${ }^{1}$ Cultural nationalism, as sociologist Anthony Smith states, cannot be strictly separated from political nationalism. ${ }^{2}$ Given that the quest for cultural identity based on the language and folk heritage was common to all nineteenthcentury national aspirations within the European cultural frame, the differences should be found in the interplay between the cultural and political aspirations of the individual nations. The starting point for a broader reconsideration of the interplay between cultural and political nationalisms should be their individual quests for cultural distinctiveness premised on the political aspirations for independence.

1 Richard Taruskin writes in the The New Grove Dictionary of Music and Musicians that nationalism is "a major factor of European cultural ideology." Taruskin, "Nationalism", 689.

2 See more in the chapter "Cultural and Political Nationalism" in Smith, Nationalism and Modernism, 177-180. 
The role of politics is evident if literary and music creativity is observed in its social context. A prominent English musicologist, Jim Samson, has adopted Hobsbawm's and Gellner's theories on the relationship between social class and nationalism and asserted a sociological thesis by distinguishing between Western and Eastern variants of nationalism based on the varying social statuses of different promoters of national ideas. ${ }^{3}$ Samson also outlined the process of transformation of Herder's Volksgeist idea into political slogans in favour of independence in the lands of the "eastern Habsburg Empire": "There is perhaps something in the argument that nationalism in Eastern Europe was qualitatively different from that in the west, that it was collectivistic and ethnic rather than individualistic and political in character." Though his assumption seems to be generally acceptable, one must not overlook the "small nations" of the European periphery and their historical particularities. In the light of cultural diversity within the multinational Habsburg Empire it seems necessary to verify Samson's assumption on the examples of the cultural and political aspirations of the individual nations (populations), as Bojan Bujić has already pointed out in his review article of Samson's book Music in the Balkans. ${ }^{5}$ To draw a more authentic cultural-historical image of Central Europe within the Habsburg Empire, we should look at more details regarding "music at the edge" and especially on their relation to the supremacy of the dominant (official) German culture. This article therefore lays out some historical details concerning nineteenth-century cultural and political aspirations of Slovenians, in order to avoid the inconsistencies in some other published discussions on nationalism that also address the geographical area inhabited by Slovenians.

Unable to constitute themselves within the framework of their own state until 1991, the Slovenes, an ethnic community and ahistorical "small nation" at the edge of Habsburg Monarchy, took culture as their existential purpose. In contrast to some other nations that lived under the Habsburg Monarchy until 1914, the Slovenian nation was not formed from the ideology of historical law, but it was the language and literature that have always been its essence. ${ }^{6}$ The central issue in this respect is how Slovenians in the past defined themselves as a nation through and with culture. The question of how the language, literature and music have been used to create identity should be considered in view of the past interaction of cultural and political aspirations on one hand, and the history of literary and musical ideas, i.e., self-defined images in literature and music, on the other. A reaction against the dominant and also official, state German culture is evident in the efforts to institutionalise Slovenian culture. On the other hand, the ways in which Slovenians have conceived of and valued their own, "authentic" literature and music are also recognisable in this relationship.

3 Samson, "Nations and nationalism", 568.

4 Samson, "Nations and nationalism", 571.

5 Bujić, "Weaving Historical Strands", 452-455.

6 Slovenian literary historian Tomo Virk considers the language and literature as an entity, a "meaning and foundation of national existence". Virk, "Slovenska nacija in slovenska literatura", 255. 


\section{Self-descriptions of Slovenians as a community before 1848}

The community of Slovenes was initially expressed by linguistic, ethnic and religious self-descriptions. It is already clear that first unified form of community was based on the common language; it was the crucial element in the formation of Slovenian community awareness from the mid-sixteenth century onwards. The first book in Slovenian, a translation of religious texts by Protestant Reformer Primož Trubar, promoted religion and the Church among people that spoke Slovenian. Trubar's translation Catechismus (1550) also contains six melodies. Although at least three of them were taken from German collections, Slovenian musicologists have recognised singing in Slovenian as a starting point for ethnically defined music. ${ }^{7}$ From Trubar's time the language became the essential identification marker for Slovenians, but the dynamism of this identification process has changed over the centuries. ${ }^{8}$ Historian Peter Vodopivec cites Kraynska grammatika (1768) by Marko Pohlin, the first Slovenian grammar written in German and one that codified the Slovenian language, as a work that proved important to the nascent national revival. ${ }^{9}$

The national revival gained new impulses from the spread of Enlightenment ideals at the end of the eighteenth century. In Carniola, the central Slovenian province at the edge of the Habsburg Empire, the population had higher social status and education levels; its citizens were multilingual and Italian and German dominated. ${ }^{10}$ Slovenian was than considered to be the language of uneducated inhabitants; it did not have well-developed vocabulary for more demanding uses and cultural needs. ${ }^{11}$ The language was thus simply a means of communication: it was a social sign and not yet an ethnic identifier. Interest in the Slovenian language itself emerged from Enlightenment ideals together with interest in folk heritage. The Franciscan priest, teacher, writer, linguist, translator and poet Valentin Vodnik (1758-1819) collected folk songs and wrote the first simple verses in Slovenian with texts similar to folk songs (Pesme za pokušino; Poems for Sampling, 1806). An inventory of the collected music folk material from Slovenian lands Carniola and Carinthia that the Ljubljana Philharmonic Society sent to Vienna in 1819 shed light on the ethnic situation of rural areas: songs in Carniolan (Slovenian) prevailed, whereas some collected songs were also German (among these also an "operetta"). ${ }^{12}$ Most of

7 Bedina, "Zgodovinska izhodišča identitete slovenskega glasbenega dela", 163-164; Loparnik, "Slovenska glasba in slovenska cerkev", 167-168.

8 In addition to Trubar's translations, other important publications increased awareness of community included the first Slovenian grammar (explained in Latin) Articae horulae succisivae by Adam Bohorič (1584) and Jurij Dalmatin's translation of the Bible (1584). See Rotar, "Narodnokonstitutivni pojmi začetnih obdobij slovenske narodne integracije", 125-132; Pogačnik, "Slovenska samobitnost v delu protestantskih piscev", 69-79.

9 Vodopivec, Od Pohlinove slovnice do samostojne države, 14-15.

${ }^{10}$ In 1754 the capital of Carniola, Ljubljana, had 9400 residents. See Vilfan, "Ljubljana. Zgodovina”, 225.

${ }^{11} \mathrm{Kmecl}$, "Kako so Slovenci v 19. stoletju pojmovali pomen literature za narod", 84.

${ }^{12}$ The Ljubljana Philharmonic Society had encouraged collecting of folk songs, folk dance melodies and hymns in Carniola and Carinthia at the initiative of the Viennese Music Society (Gesellschaft der Musikfreunde). Due to its modest results and ethnological purpose, this collection was not of much significance for Slovenian identity. 
the songs in Slovenian were hymns, some of them with the note "translation from the German". ${ }^{13}$ On the other hand, literary and musical efforts in Slovenian were artistically irrelevant; in the late eighteenth century they were "only of partial indirect importance for self-identification of Slovenians", as Andrej Rijavec stated. ${ }^{14}$ Literary texts in Slovenian were "merely" translations or adaptations from Italian and French literature. The modest incidental music of Slovenian composer Janez Krstnik Novak (around 1756-1833) Figaro evidently followed Mozart's example. ${ }^{15}$

In the pre-March era, the only nationally defined music in Slovenian was Catholic hymns. Singing in Slovenian was an expression of an awareness of the religious and ethnic community. Their texts identified the moral with the social and the religious with the secular. The composers, mainly amateur musicians, wrote emotional melodies with simple homophonic accompaniments. ${ }^{16}$ These songs were popular and their tunes were close to folk songs of the Austrian-German musical idiom. As Borut Loparnik noted, they represented a symbiosis between folk-, Liedertafel and Biedermeier entertainment. ${ }^{17}$

\section{Slovenian cultural aspirations after 1848}

The first political tendencies toward unifying Slovenians settled in different Austrian provinces emerged in the mid-nineteenth century. The first Slovenian political programme from 1848, called United Slovenia (Zedinjena Slovenija), encouraged the national consciousness with the demand of uniting the lands with Slovenian populations on the basis of unifying the written language without regional speaking variants. The founding members of the Slovenian Society (Slovensko društvo), which was active from 1848 to 1853 in Ljubljana, shared the opinion that the language was that true foundation on which the consciousness of belonging to the Slovenian nation could grow. In its aims and goals, the society was a cultural rather than political association. Patriots endeavoured to promote Slovenian language ${ }^{18}$ and its development with speeches and choral singing, while the

${ }^{13}$ See Keesbacher, Philharmonische Gesellschaft, 46-49.

${ }^{14}$ Rijavec, "Glasbene težnje na Slovenskem ob vstopu v 19. stoletje", 108.

${ }^{15}$ The most prominent Slovenian scholar and writer at the end of the eighteenth century, Anton Tomaž Linhart, adapted Beaumarchais's comedy La Folle Journée ou le Mariage de Figaro. It was published under the Slovenian title Ta veseli dan ali Matiček se ženi in 1790. Janez Krstnik Novak composed music to some parts of this text, Figaro, evidently following Mozart's example. The exact date of the first performance of this incidental (theatre) music is unknown. Nowadays it is recognised for its historical value. See Nagode's commentary in his edition of Janez Krstnik Novak's Figaro, IX-X.

16 The most important composer of Catholic hymns in the pre-March era was Gregor Rihar (1796-1793), choirmaster and organist of the Ljubljana Cathedral. His songs were very popular and some of them have been adopted as folk songs. He composed about five hundred chants, of which almost four hundred were published.

${ }^{17}$ Loparnik, "Slovenska glasba in slovenska cerkev", 167-168.

${ }^{18}$ It should be noted that Slovenian was in the middle of the nineteenth century still in the development stage at that time and had acquired the necessary linguistic foundations to be comparable with other developed and widely spoken languages. 
official German language continued to have a communication role in everyday and social life among educated citizens.

After the end of absolutism in the Habsburg Monarchy the source of growing bourgeois nationalism among Slovenian patriots was the quest to find the "Slovenian spirit"; Matjaž Barbo used the phrase "musical emotions of the lower layer". ${ }^{19}$ Slovenian bourgeois music-making was music of the "folk" and was created to be performed. In the call for the best musical setting of a poem by the (then renowned but today already forgotten) Slovenian poet Jovan Vesel Koseski, the Slovenian conservative politician, editor and cultural arbiter Janez Bleiweis wrote in 1862: "the song should be composed in the national spirit, as easy to sing as possible and melodious, so that it would secure a place in the nation and not remain locked in the concert hall [...] to hear it sung by the folk". ${ }^{20}$ "A national spirit" was equated with the "folk spirit" and demands for simplicity were pragmatic. Such an imperative that emphasised the needs of "common man" followed the pragmatic and educational principle of cultural nationalism, that is, according to John Hutchinson, striving for "a moral regeneration of the community". ${ }^{21}$

Amateur Slovenian musicians with the syncretistic type of creativity wrote melodies and simple verses imitating folk songs in the 1850 s and 1860 s or set to music simple national-awakening verses by other patriots. ${ }^{22}$ After 1870 , lyrical poems by younger generations of poets ${ }^{23}$ were also set to music. Music production was a direct response to the national need and (national) desire for a "common man". This music, written according to a collectively accepted pattern, was the direct expression of patriotic feelings and followed the musical patterns of generally accepted popular Catholic hymns and the universal Liedertafel style. The melodies and lyrics were the product of collective creativity, closely connected with the "folk song". In view of the creative process the "folk song" and "art song" were not separate notions. Until the 1860s, the most popular songs were those by Miroslav Vilhar (1818-1871) and Jurij Flajšman (1818-1874). Despite the absence of individualist characteristics in Flajšman's artistic production, the Slovenian pre-war writer and composer Pavel Kozina considered him "the father of Slovenian art music", ${ }^{4}$ only later have musicologists come to see Flajšman's work as a preliminary phase of art music.

In his own time, Flajšman was compared with the "first Slovenian poet" Valentin

${ }^{19}$ Barbo, “'Slovenski duh' kot poetska kategorija”, 36.

${ }^{20}$ Bleiweis, "Razpis darila za najbolji napev", 155: "Pesem mora biti v narodnem duhu zložena in kolikor mogoče lahka za petje, melodična, da bo segla v narod, ne pa se zaprla samo v dvorano 'besede' ali koncerta [...] da jo slišimo prepevati od ljudstva."

${ }^{21}$ Cit. in Smith, Nationalism and modernism, 177.

${ }^{22}$ The Songbook (Pesmarica), edited by patriot Radoslav Razlag and printed in Graz in 1863 , includes three hundred texts of the song that were "well known and sung on Slovenian ethnic territories". Simple national-awakening verses wrote among others well known Slovenian patriots and politicians: Davorin Terstenjak, Lovro Toman, Gregor Krek, Radoslav Razlag, Fran Cegnar and Andrej Praprotnik. See Učitejski tovariš 3, no. 16 (1863): 256.

${ }^{23}$ The texts of poets Simon Jenko (1835-1869), Josip Stritar (1836-1923) and Simon Gregorčič (1844-1906).

${ }^{24}$ Kozina, “Jurij J. Fleišman, oče slovenske umetne glasbe”, 209. 
Vodnik, the most valued Slovenian poet until the $1860 \mathrm{~s} .{ }^{25}$ In addition to Vodnik's pragmatic poetry, around the middle of the nineteenth century a book of poetry appeared by a man of more liberal views, a "free thinker" (Freigeist), who broke with this conservative and collective accepted creativity. This was a change from what had until then been regarded as Slovenian. France Prešeren's book Poezije (Poetry), published in 1847, at first was not well received. Prešeren (1800-1849), who studied law in Vienna, was a bilingual poet: he wrote in Slovenian and German. His poetry elevated the Slovenian language to an artistic level and was a departure from the form and content of poetry with which Slovenians then identified themselves; that is, from simple songs "in the spirit of the people" that glorify the beauty of the Slovenian land and people. ${ }^{26}$ Only two decades after Prešeren's death, his poetry was acknowledged as a nationally representative literary achievement. Due to its "bourgeois content", according to Matjaž Kmecl, a situation similar to that of Prešeren's poetry happened with the reception of Josip Jurčič's novel Deseti brat (The Tenth Brother) in 1866;27 today it is heralded as the first Slovenian novel.

In 1877 the first historical overview on music in Slovenian lands Frau Musica in Krain (Madame Musica in Carniola) was published by historian Peter Radics; this booklet, with the note "a cultural-historical outline", was written in German. The music was observed as cultural praxis and not as art. The title of the booklet reveals also the author's mental habitus and views; it express his provincial (Carniolan) but not yet national consciousness. A decade later the teacher Fran Rakuša wrote a Slovenian-language overview of musical works by Slovenians with the indicative title Slovensko petje v preteklih dobah (Slovenian Singing in Past Eras, 1890). The title exposed the importance of the language and text for nationally-defined music-making in Slovenian ideas of culture and music at the end of nineteenth century.

\section{Slovenian cultural and political nationalism at the end of the nineteenth century}

Demands for cultural unification were a prelude to demands for political unification of the lands inhabited by Slovenians. The interplay of Slovenians' cultural and political aspirations was more evident in the last decades of the nineteenth century. After 1870 the Slovenian nationalist movement, together with the increasing separation of liberal and Catholic thought, obtained an actively political form. There was a noticeably stronger political impact in the Slovenian requirements for independence in their cultural endeavours as well. These changes also influenced the programme of the Ljubljana Music Society (Glasbena matica, est. 1872), which explicitly supported Slovenian music. With this declarative nationalist founding principle, the Music Society considered the "German" Philharmonic Society

${ }^{25}$ Every year on Vodnik's birthdate, a special patriotic cultural event was held in Ljubljana in honour of the poet; a monument to him was erected in 1889.

${ }^{26}$ Although the musical settings of his poems did not have national-awakening content, the first setting of his Slovenian poem was performed during the poet's lifetime in 1848. See the list of the musical settings of Prešeren's poems in: Bulovec, "Prešeren v glasbi", 90-116.

${ }^{27} \mathrm{Kmecl}$, "Kako so Slovenci v 19. stoletju pojmovali pomen literature za narod", 89-90. 
to be a rival. The Philharmonic Society (Philharmonische Gesellschaft), established in 1794 and posing its cultural aspirations against the previously dominant Italian music culture, promoted German (Austrian) as well as cosmopolitan musical culture. In this, it followed the musical trends of the imperial capital, Vienna. In contrast to its German counterpart, the Slovenian Music Society distinctly identified itself as a nationalist association. It endeavoured to ensure the autonomy of Slovenian musical culture and the institutionalisation of musical interests on a national basis; objectives it clearly defined in its regulations as "supporting and cultivating Slovenian national music". ${ }^{28}$ Its cultural connections with similar music and cultural societies of various Slavic nations facilitated successful competition against the German culture.

The concept of identity within the framework of the society's activity included two aspects: first, being distinct from "the other"; that is, distinct from the official German language-based culture; and second, establishing an awareness of continuous cultural presence (historicity). The substance of the Music Society's work was strengthening musical culture on a national basis. Their programme followed three main guidelines: concern for the development of vocal music, especially of mass choral singing; collecting the folk and artistic music heritage of Slovenians; and the gradual professionalisation of musical work. With the founding of their own Slovenian music school, music-publishing house and concert agency, which operated entirely in Slovenian, they planned to support endeavours for Slovenians' cultural independence. Their consistent commitment to the Slovenian language in the publishing, educational and concert activities of the Music Society reveals the political aspirations of the society's board. The Music Society established Slovenian music schools at the end of the nineteenth and early twentieth centuries all over Slovenian ethnic territory and gradually developed significance as the central Slovenian music association. The concept of Slovenians' own "otherness" was still based on use of the Slovenian language and folklore, which represented the essence and point of identification for the entire Slovenian culture even in the last decades of the nineteenth century. The Music Society had the texts of foreign musical works translated into Slovenian for concert performances, and likewise the texts of Croatian, Serbian and Bohemian choruses that they published. The music of the "folk" was still the symbol of nationalism and collective expression of national identity. The Society fostered belief in the originality of the Slovenian musical idiom by publishing the simple arrangements of folk songs for choral singing and by encouraging new compositions to be created "in the folk spirit". Folksiness (Ger. Volkstümlichkeit) mainly had a social connotation and was not codified by concrete musical parameters. Solo songs with emotional melodies and simple accompaniments were imitations of folk songs. Most of the editions published in the $1870 \mathrm{~s}$ and 1880 s contained new choral works following the universal Liedertafel style. Close to folk music in its content, and utterly uncomplicated in its musical and technical aspects, this music was recognisable, comprehensible and accepted. It was thus easily accepted and became very popular. One could say that at the end of nineteenth century "simplicity

\footnotetext{
${ }^{28}$ Pravila Glasbene Matice v Ljubljani, 1.
} 
was attendant to popularity", as Matthew Gelbart wrote, ${ }^{29}$ and "folk music", "art music" and "popular music" in regard to their contents were not yet strictly separate categories.

The Music Society consolidated the idea of a permanent cultural existence (historicity) at the end of the nineteenth century by presenting historical concerts: one featuring the works of Iacobus Handl Gallus, a Renaissance composer of Slovenian origin (1892), and one featuring Slovenian Protestant sacred songs from the sixteenth and seventeenth centuries arranged for chorus (1893). This concert characteristically revealed everything that was believed to represent identity at that time: here the language was prioritised, along with choral singing, while the originality of the melodies was not a topic of discussion.

At the end of the nineteenth century large choir of Music Society (containing over one hundred singers) and folklore were regarded as national representatives. ${ }^{30}$ The choir received special acknowledgements for its performances of Slovenian vocal music, especially cantatas. Among these, the most successful were compositions by Franciscan priest Hugolin Sattner, who set texts by Simon Gregorčič (Jeftejeva prisega, Oljki, Soči) to music. Both authors took into account the abilities, musical tastes and expectations of the widest circles of music consumers, performers and audiences and were therefore considered a "folk poet" and "folk composer". An exemplary musical artefact of the Slovenian variant of music nationalism is the first oratorio in Slovenian, Assumptio (Vnebovzetje) composed by Sattner (text by Mihael Opeka) in 1912, which was received by Slovenians with great acclaim.

With its call for the best musical setting of texts by society member, poet and priest Simon Gregorčič (1844-1906) the year after his death (1907), the Music Society anointed this most popular Slovenian "folk poet" as its literary hero. The winning compositions were performed the next year at an occasional concert to raise funds for the poet's monument. In addition to the Gregorčič concert, the Music Society held some other occasional concerts that were dedicated to popular Slovenian writers and composers. Their names also reveal the literary and musical reception of the time: poet France Prešeren (1900), composer Davorin Jenko (1910) ${ }^{31}$ and composers Gustav, Benjamin and Josip Ipavec (1914). The selection of both the conservative Gregorčič and more liberal and individualistic poet Prešeren shows that Slovenians identified themselves with the collective, "folksy" creativity as well as with individual achievements. This (apparent) dichotomy is less

${ }^{29}$ Matthew Gelbart feels that folk-like music was "popular" because it was simple, touching and universal. See Gelbart, The Invention of "Folk Music" and "Art Music", 257.

${ }^{30}$ In this respect is indicative the reception of a concert given by the Slovenian Music Society choir in Vienna in 1896. Accompanied by the Vienna Opera orchestra, the Slovenian choir performed Austrian, Bohemian and Slovenian repertoire: Bruckner's Te Deum, Fibich's Frühlingsromanze, Dvořak's cantata Svatebni košile (The Spectre's Bride) in Slovenian translation (!), a madrigal by Gallus Musica noster amor, two other Slovenian choruses popular at that time (by two Czech composers that worked in Ljubljana, Antonín Foerster and Antonín Nedvěd) and Slovenian folk songs arranged for mixed chorus. The later were - in addition to Gallus's madrigal - met by the warmest acclaim in Vienna. Izvestje Glasbene matice v Ljubljani, 9-48.

31 The reason for holding the Jenko concert was the fiftieth anniversary of his patriotic march Naprej zastava Slave (With Slava's Banner Forwards) which Slovenians accepted as their (unofficial) national anthem. 
pronounced in music. To some extent it is reflected in works by the Ipavec brothers. The reason for their artistic (aesthetic) diversity is hidden in their extramusical context: they lived and worked in a different national and social environment. ${ }^{32}$

At the turn of the centuries, differentiation between German and Slovenian music seems acceptable only if the focus is on the conditions for musical work as the result of political aspirations for institutional independence. Musical life in the capital of the central Slovenian land, Ljubljana, was institutionalised on the pattern of other provincial Habsburg cities. At the end of the nineteenth century a new segregation of (musical) culture in Ljubljana came about through the establishment of the Slovenian Provincial Theatre (Slovensko deželno gledališče, 1892) and of the first civic concert orchestra, the Slovenian Philharmonic (Slovenska filharmonija, 1908-1913). The political status of the Slovenian community changed after World War I, following the disintegration of the Habsburg Monarchy and the subsequent establishment of the new Kingdom of Serbs, Croats and Slovenes. The "German" Philharmonic Society was forced to halt its activities (i.e., it was abolished). This new political situation created new institutional possibilities and incentives in music. Only in 1919, after long-standing efforts, did the Music Society accomplish its most important goal by establishing a music conservatory, thus accelerating the process of separating amateur from professional musical work. The conservatory offered a higher level of music education that promoted different musical goals and also individual engagement; that is, it was the essential agent for the constitution of a musical identity. Thus, the nationalism or nationalistic attitude of the Music Society's board was a vital factor for further development of Slovenian national music, because it put in place the institutional foundations required for the professionalization of music.

\section{Nineteenth-century self-defined images of Slovenians in literature and music}

Because of the decisive role of the language and folklore as identification symbols, the idiom of nineteenth-century Slovenian vocal music - although it seems paradoxical at first sight - was closer to the universal than to the national and was hence a transhistorical phenomenon. Although Catholic hymns in Slovenian and other secular vocal music after 1848 written "in the Slovenian spirit" had, according to Barbo, a "historical significance in creating a Slovenian national style", ${ }^{33}$ from a musical point of view they contained no stylistic particularities. Their national representativeness is evident only in the language and the subject matter of texts that celebrated beauty of the Slovenian land and people; that is, the ethnic and ethical essence of the nation. In this respect the subject matter of the first operetta (later adapted into an opera) in Slovenian, Gorenjski slavček

${ }^{32}$ Benjamin Ipavec (1929-1908) lived and worked as a physician in the bourgeois milieu of Graz and composed salon music; his brother Gustav Ipavec (1831-1908), also a physician, lived and worked in the rural milieu of his home town Šentjur (near Celje) and composed folklorised vocal music. Gustav's son Josip (1873-1921), who worked as a physician in Vienna, Zagreb and Šentjur, composed more ambitious works.

${ }^{33}$ Barbo, "'Slovenski duh' kot poetska kategorija”, 37. 
(The Nightingale from Upper Carniola; Ger. Krainer Nachtingale), written by composer Anton Forester, Czech by origin, is also illustrative. It glorifies a rural community of Slovenians and not any exceptional individual or national hero. Identification with folk life (the peasantry, equated with the nation) and symbols such as Mt. Triglav or a lime tree made this opera the most popular Slovenian opera. ${ }^{34}$ From a musical point of view, the identification process was triggered by the inclusion of folkloristic elements. Foerster's music incorporated a generally recognised popular, Alpine idiom, that was widespread and popular not only in the Austrian milieu but all over Europe. Peasants were musically characterised by collective singing of "folk songs". It gained great national significance also in part due to the circumstances of its premiere in 1872: it won the first prize in a competition of the newly-established Slovenian Dramatic Society. Because of its "sublime melodies" and greater performance requirements it was described as an "art(istic)" work. ${ }^{35}$ The more or less permanent presence of this opera in the repertoire up to today reveals that, despite the absence of content that would relate to a glorious national history, Gorenjski slavček is received by Slovenians as a "national opera". ${ }^{36}$ Folk songs functioned as national markers even if they were sung in another language; namely, the composer Forester himself requested that the piano-reduction of this opera be printed (1901) with both the Slovenian and German texts. This fact raises the question of whether Foerster saw himself as Slovenian, Slavic or rather as a universal, eclectic composer. However, this "folk-like" music remains popular even today despite its universal model. In contrast, Teharski plemiči (The Noblemen of Teharje) by Benjamin Ipavec, which was first staged in 1892 and was based on a historical subject taken from a folk tale, did not remain in the repertoire due to its lack of compelling drama in the libretto and the music.

\section{Cultural memory of Slovenians}

Slovenian literary historian Vladimir Osolnik considers the literature "a solid foundation of Slovenian national and individual identity". ${ }^{37}$ The current Slovenian cultural memory predominantly consists of Slovenian poets and writers, individuals that - each in their own era - broke away from what was then believed to be typically and "genuinely" Slovenian. The answer to why Slovenians today mainly identify themselves with literature; that is, by their "great poets and writers", is found in the Slovenian philosopher Mladen Dolar's thesis that national identity is also based on individual departures from conventional artistic norms: "Every identity requires both individual and collective engagement, which demands departure from what we consider as well-known and 'ours', to break the ties

${ }^{34}$ Smetana's opera The Bartered Bride was similarly received in his homeland. It is certainly not mere coincidence that Foerster, the composer of The Nightingale of Upper Carniola, was Smetana's pupil.

${ }^{35}$ Novice gospodarske, obrtniške in narodne, 1 May 1872.

${ }^{36}$ Even as late as 1940 composer Matija Tomc wrote that this was "the only Slovenian opera to have outlived all others", due to Foerster's naive easiness and warmth held dear by the Slovenian people. See Matija Tomc, “Operna sezona 1939/1940”, Dom in svet 52, no. 7 (1940): 433.

${ }^{37}$ Osolnik, "Nekaj besed o jeziku, književnosti in nacionalni identiteti na Slovenskem", 315. 
that bind us to the roots, to make foreign what has so far been domestic." ${ }^{38}$ Poet Prešeren was, according to literary historian Boris Paternu, "the first to independently supersede the tradition of pragmatic literature". ${ }^{39}$ According to literary historian Tomo Virk, the "sacralisation" of poet Prešeren as the greatest Slovenian poet self-evidently promoted the selection of his text as the current national anthem..$^{40}$ His verses of the seventh stanza of the poem Zdravljica (A Toast) ${ }^{41}$ written in 1844, glorify peaceful coexistence between nations: "God's blessing on all nations!" 42 It was the poet's personal vision of internationalism and represented a departure from the content of other poetry in Slovenian.

The "canonisation"43 of poet France Prešeren reveals that Slovenians today identify themselves with his poetry and with literature in general. ${ }^{44}$ The question of how Slovenians can defined their own music identity should be therefore focused on the relation between canonical and popular repertoires vs. original creativity. Unlike poet Prešeren, nineteenthcentury Slovenian composers (or Czech ones that worked in Slovenian lands) were either unable to or did not want to supersede the collective creative level and the commonly expected popular music canon, based on the model of well-received Catholic hymns in Slovenian. The unambitious creative drive of Slovenian composers in the second half of the nineteenth century prevented the realisation of "a reaction against the supremacy of German music", as Willi Apel defined musical nationalism fifty years ago. ${ }^{45}$ Therefore Slovenian nineteenth-century music was only a local version of a globalised European idiom, described by Gregor Pompe as a "global fact captured in the intellectual history and political-national characteristics of Central Europe". ${ }^{46}$ In other words, due to the above

38 “Za vsako identiteto, vredno tega imena, je potrebno določeno dejanje tako na individualni kot na kolektivni ravni, ki terja odmik od dotlej znanega in 'našega', prerezanje niti, ki nas vežejo na korenine, potujitev dotlej domačega." See Dolar, "Slovenska nacionalna identiteta in kultura", 33.

${ }^{39}$ Paternu, "France Prešeren in problem identitete", 81.

${ }^{40}$ Virk, "Slovenska nacija in slovenska literatura", 256.

${ }^{41}$ Janko Lavrin translated the seventh stanza of Prešeren's poem A toast: "God's blessing on all nations / Who long and work for that bright day / When o'er earth's habitations / No war, no strife shall hold its sway; / Who long to see / That all men free / No more shall foes, but neighbours be." See: "France Prešeren: Zdravljica (A Toast)",http://www.vlada.si/en/about_slovenia/political_system/national_insignia/france_preseren_zdravljica_a_toast/(Accessed 5 January 2016).

${ }^{42}$ The text of Zdravljica gradually acquired a more pronounced political connotation and was, now accompanied by Stanko Premrl's musical setting, written in 1905 in Liedertafel style, accepted in 1991 as the official national anthem. Premrl set Prešeren's poem Zdravljica to music more than half a century after it had been written, namely in 1905. The first version of Premrl's setting was a mixed chorus on the first, second and fifth stanzas of the poem. Only a few years later did Premrl arrange his music for male chorus and add the seventh stanza, which now serves as the national anthem. See more in: Cigoj, "Himna kot simbol naroda", 11-28.

${ }^{43}$ Dović, "O kulturnih svetnikih in kanonizaciji”, 5-6.

${ }^{44}$ The central square in Slovenia's capital features a monument to Prešeren and bears his name; the day of his death has been declared a national holiday: Culture Day.

${ }^{45}$ Cit. in Taruskin, "Nationalism", 689.

${ }^{46}$ Pompe based his argument on a comparison between some melodies by Slovenian authors and Liedertafel style examples by German authors. See Gregor Pompe, "Avtonomno in uporabno lokalna zgodovinska dilema ali transhistorično dejstvo?", 59. 
described interplay between cultural and political aspirations of Slovenians on one hand, and the absence of individual engagement on the other, according to Mladen Dolar's thesis, it was not even possible to seek the real musical "otherness".

\section{Bibliography}

Barbo, Matjaž. »'Slovenski duh'« kot poetska kategorija«. Muzikološki zbornik 29, no. 2 (1993): 33-38.

Bedina, Katarina. "Zgodovinska izhodišča identitete slovenskega glasbenega dela”. In Avstrija. Jugoslavija. Slovenija. Slovenska narodna identiteta skozi čas, edited by Dušan Nećak, 152-167. Ljubljana: Oddelek za zgodovino Filozofske fakultete, 1997.

Bleiweis, Janez. "Razpis darila za najbolji napev". Novice gospodarske, obrtniške in narodne, 14 May 1862.

Bujić, Bojan. "Weaving Historical Strands". Journal of the Royal Association 140, no. 2 (2015): 451-467.

Bulovec, Štefka.“Prešeren v glasbi”. Muzikološki zbornik 1, no. 1 (1965): 90-116.

Cigoj Krstulović, Nataša. "Himna kot simbol naroda: premislek ob stoletnici nastanka Premrlove Zdravice”. De musica disserenda 1, no. 1-2 (2005): 11-28.

Zgodovina, spomin, dediščina. Zgodovina ljubljanske Glasbene matice do konca druge svetovna vojne. Ljubljana: Založba ZRC, ZRC SAZU, 2015.

Dolar, Mladen. "Slovenska nacionalna identiteta in kultura - navodila za uporabo". In Nacionalna identiteta in kultura, edited by Neda Pagon and Mitja Čepič, 21-35. Ljubljana: Inštitut za civilizacijo in kulturo, 2003.

Dović, Marjan. »O kulturnih svetnikih in kanonizaciji«. Kulturni svetniki in kanonizacija. Slovenski in evropski kontekst, izvlečki simpozija, edited by Marjan Dović and Alenka Koron, 5-6. Ljubljana: Inštitut za slovensko literaturo in literarne vede ZRC SAZU, 2015.

Gelbart, Matthew. The Invention of "Folk Music" and "Art Music". Emerging Categories from Ossian to Wagner. Cambridge: Cambridge University Press, 2007.

Izvestje Glasbene matice v Ljubljani o društvenem in šolskem letu 1897/8. Ljubljana: Glasbena matica, 1898.

Keesbacher, Friedrich. Philharmonische Gesellschaft. Ljubljana: Filharmonična družba, 1862.

Kmecl, Matjaž. "Kako so Slovenci v 19. stoletju pojmovali pomen literature za narod". In XXVIII. Seminar slovenskega jezika, literature in kulture, 29. 6. - 18. 7. 1992, zbornik predavanj, edited by Miran Hladnik and Darinka Počaj-Rus, 83-90. Ljubljana: Filozofska fakulteta, 1992.

Kozina, Pavel. "Jurij J. Fleišman, oče slovenske umetne glasbe”. Življenje in svet 4, no. 8 (1930): 209-213.

Loparnik, Borut. “Slovenska glasba in slovenska cerkev: 19. stoletje”. In Vloga Cerkve v slovenskem kulturnem razvoju 19. stoletja, edited by France Dolinar, Joža Mahnič and Peter Vodopivec, 153-173. Ljubljana: Slovenska matica, 1989.

Novak, Janez Krstnik. Figaro. Cantate zum Geburts oder Namenfeste einer Mutter, 
Monumenta artis musicae Sloveniae, vol. 47, edited by Aleš Nagode and Zoran Krstulović. Ljubljana: Založba ZRC ZRC SAZU, 2004.

Osolnik, Vladimir. "Nekaj besed o jeziku, književnosti in nacionalni identiteti na Slovenskem”. Anthropos 39, no. 3-4 (2007): 314-323.

Paternu, Boris. "France Prešeren in problem identitete". In XXVIII. seminar slovenskega jezika, literature in kulture, 29. 6.- 18. 7. 1992, edited by Miran Hladnik and Darinka Počaj-Rus, 81-82. Ljubljana: Filozofska fakulteta, 1992.

Pogačnik, Jože. "Slovenska samobitnost v delu protestantskih piscev". In XXVIII. seminar slovenskega jezika, literature in kulture 29. 6.- 18. 7. 1992, edited by Miran Hladnik and Darinka Počaj-Rus, 65-80. Ljubljana: Filozofska fakulteta, 1992.

Pompe, Gregor. "Avtonomno in uporabno: lokalna zgodovinska dilema ali transhistorično dejstvo?". De musica disserenda 2, no. 2 (2006): 53-64.

Pravila Glasbene Matice v Ljubljani. Ljubljana: Glasbena matica, 1872.

Radics, Peter. Frau musica in Krain. Kulturgeschichtliche Skizze. Ljubljana: Ig. v. Kleinmayr \& Fed. Bamberg, 1877.

Rakuša, Fran. Slovensko petje v preteklih dobah. Ljubljana: Narodna tiskarna, 1890.

Rijavec, Andrej. “Glasbene težnje na Slovenskem ob vstopu v 19. stoletje”. In Obdobje slovenskega narodnega preporoda. Mednarodni simpozij v Ljubljani od 28. do 30. junija 1989, edited by Matjaž Kmecl, 107-111. Ljubljana: Filozofska fakulteta, Znanstveni inštitut, 1991.

Rotar, Janez. "Narodnokonstitutivni pojmi začetnih obdobij slovenske narodne integracije". In XXVIII. seminar slovenskega jezika, literature in kulture 29. 6. - 18. 7. 1992, edited by Miran Hladnik and Darinka Počaj-Rus, 123-148. Ljubljana: Filozofska fakulteta, 1992.

Samson, Jim. "Nations and nationalism". The Cambridge history of nineteenth-century music, edited by Jim Samson, 568-600. Cambridge: Cambridge University Press, 2002.

Smith, Anthony D. Nationalism and Modernism. A critical survey of recent theories of nations and nationalism. London and New York: Routledge, 1998.

Taruskin, Richard. "Nationalism". The New Grove Dictionary of Music and Musicians, edited by Stanley Sadie, executive editor John Tyrrell, vol. 17, 2. edition, 689-706. London: Macmillan Publishers Limited, 2001.

Tomc, Matija . “Operna sezona 1939/1940”. Dom in svet 52, no. 7 (1940): 433.

Vilfan, Sergij. "Ljubljana. Zgodovina”. Enciklopedija Slovenije, vol. 6, 220-226. Ljubljana: Mladinska knjiga, 1992.

Virk, Tomo. "Slovenska nacija in slovenska literatura". Nova revija 12, no. 134/135 (1993): 254-260. (Thematic issue Slovenians and Future / Slovenci in prihodnost).

Vodopivec, Peter. Od Pohlinove slovnice do samostojne države. Slovenska zgodovina od konca 18. do konca 20. stoletja, 4. izdaja. Ljubljana: Modrijan, 2010. 


\section{JEZIK, LITERATURA IN GLASBA V KULTURNIH IN POLITIČNIH PRIZADEVANJIH SLOVENCEV PRED 1914}

\section{Povzetek}

Literarne in glasbene podobe samo-identifikacije, ki so se vtisnile v kulturni spomin Slovencev, odstirajo vlogo jezika, literature in glasbe v kulturnih in političnih prizadevanjih v okviru večnarodnostne habsburške monarhije v različnih zgodovinskih obdobjih do leta 1914. Petje cerkvenih pesmi v slovenskem jeziku je bilo v predmarčnem času izraz jezikovne, etnične in verske skupnosti, po letu 1848 pa je bilo zborovsko petje pesmi v slovenskem jeziku znamenje prebujene narodne zavesti. Njegova reprezentativna vloga se je navzven kazala skozi jezik, sporočilnost besedila in »slovenski duh«, ki je izhajal iz ljudsko pojmovane glasbene osnove. Nazoren primer zgodovinske samo-identifikacije, ki je izhajala iz jezika in folklore, sta tudi glasba in libreto do danes recepcijsko najbolj uspešne operete (opere) Gorenjski slavček (1872).

Stališče o nacionalnem profiliranju glasbenega dela se zdi sprejemljivo v primeru, ko postavimo v ospredje pogoje za glasbeno delo, še zlasti politično in etnično spodbujene težnje in s tem neumetniški kontekst. V nasprotju z ljubljansko Filharmonično družbo, ki se je prvenstveno zavzemala za umetniška načela in je sledila glasbenim trendom prestolnice habsburške monarhije - Dunaja, je načelno in dosledno zavzemanje za slovenski jezik na področju založniške, izobraževalne in koncertne dejavnosti ljubljanske Glasbene matice (ust. 1872), nekdaj tudi osrednjega glasbenega foruma Slovencev, razkrivalo jasne politične težnje njenega odbora. Kazala so se skozi osamosvojitvene cilje, prizadevanja za institucionalizacijo glasbenega dela na narodni osnovi in njegovo profesionalizacijo. Z glasbenega stališča je društvo še naprej podpiralo ustvarjalnost »v ljudskem duhu«, s katero so se identificirali najširši sloji. Prepoznaven je bolj ali manj enoten tok skupinske ustvarjalnosti, saj glasbeni ustvarjalci niso zmogli ali niso hoteli preseči splošno sprejetih kompozicijskih vzorcev, s katerimi so se Slovenci poistovetili. Na glasbenem področju so bile skladbe vsaj do 1914 avtorsko večinoma manj izrazito zaznamovane.

V nasprotju s situacijo na glasbenem področju v 19. stoletju pa so v literarni ustvarjalnosti tega časa poleg pričakovanih folkloristično obarvanih in s tem popularnih del prepoznani tudi individualni odmiki. Kanonizacija pesnika Prešerna kot največjega slovenskega pesnika je potrditev trditve filozofa Mladena Dolarja, da so (bili) za vzpostavitev nacionalne identitete potrebni tako skupinska ustvarjalnost kot tudi individualni presežki, se pravi odmik od tistega, kar je v določenem času in prostoru veljalo za tradicijo. V primeru glasbenih teženj Slovencev se dejanja glasbenega nacionalizma, ki ga je W. Apel opredelil kot reakcijo proti nemški glasbi, prav zaradi skupinske ustvarjalnosti in vztrajanja pri tistem, kar je veljalo za tradicijo, do začetka 20. stoletja niso mogla uresničiti. 